\title{
Observations on the Seedling Anatomy of Certain Sympetalae.
}

\author{
I. Tubiflorae.
}

BY

E. LEE, F.L.S.

Lecturer in Botany, Birkbeck College, University of London.

With Plate LXVIII and eight Diagrams and Figures in the Text.

\section{HISTORICAL.}

DURING recent years our knowledge of seedling anatomy has been extended in nearly every direction. The researches of Van Tieghem $(25,26)$ about 1870 were followed by the published observations of many continental workers (chiefly 5, 7, and 28); but, as was almost inevitable in an unexplored branch of the subject, the researches carried out during this initial stage, with one notable exception (Vuillemin, 28), concerned only scattered species from the largest classes of plants. As published papers on this subject became more numerous, the method of attack changed. The publications of Sargant $(13,14,15,16)$ resulted in the systematizing of the observations on seedling anatomy. This has been especially the case with British workers, who have taken definite groups and have conducted their observations on large numbers of species within each group. The result is that, in place of the isolated observations often so favourable to theorists, there is now a solid body of evidence rather disturbing to certain phylogenetic hypotheses, but undoubtedly valuable in other directions. The recent work of Chauveaud (2) has shown that seedling anatomy may possess an evolutionary value quite different from that hitherto assigned to it; while the physiological aspect of this subject still remains almost untouched.

Hitherto systematic research on seedling structure of Dicotyledons has concerned chiefly certain groups among the Archichlamydeae of Engler $(4,6,8,9,11$, and 20). Apart from the work of Vuillemin (28) on the Compositae, observations on the Sympetalae have, for the most part, been scattered. In 1849 Clos, who, perhaps, may be described as the first

[Annals of Botany, Vol. XXVI. No. CIII. July, 1912.] 
seedling anatomist, showed that the collet could be defined anatomically, and referred very briefly to the vascular anatomy of a few species among the Sympetalae (3); and about twenty years later Van Tieghem $(25,26)$ described the transition phenomena in a few examples from the same group. A decade later was published an account of the careful work of Gerard (7), which included a description of the seedling structure of nearly a score of examples belonging to the Sympetalae. Several of the same species have been included in the present research, which, except in details, confirms and extends this branch of Gerard's work. Of Vuillemin's memoir on the Compositae (28) more will be said in a future paper on that group. P. A. Dangeard (5), who extended Gerard's observations on the Sympetalae, classified his results on the basis of the number of strands present in the root; while Van Tieghem, in defining his three types of transition (27), also included a few examples from the same group. In I 890 Scott (18) described the seedling anatomy of Ipomoea versicolor; and a little later Scott and Brebner, in their paper 'On Internal Phloem in ... Dicotyledons' (19), and Lamounette (12), working independently on the same subject, incidentally included a description of the transition phenomena in various Sympetalae. It remains only to mention the more recent publications of Tansley and Thomas $(21,22)$, and Thomas (23), in which the seedling anatomy of certain members of this group is described in a more general manner.

\section{Scope AND Methods.}

In the present paper only a few of the better-known orders of the Tubiflorae will be considered; in these the seedling anatomy of selected species will be described, and the results of other workers will be included. The methods adopted are similar to those described by Hill and de Fraine (10). When possible, series of transverse sections of three seedlings of each species were cut with the microtome, and longitudinal sections were also made for comparison. For staining, combinations of gentian violet and vesuvin, and safranin and lichtgrün, were found to give the best results.

For the majority of the seedlings and for much kindly advice as to methods I am indebted to Mr. T. G. Hill. The greater portion of the material was grown at the Chelsea Physic Garden, and to Mr. W. Hales, the Curator, I wish to express my sincere thanks.

\section{DESCRIPTION OF SpECIES.}

\section{Convolvulaceae.}

Convolvulus tricolor, L., var. major. Seedlings large, each with massive hypocotyl (often more than $6 \mathrm{~cm}$. long) and two slightly unequal cotyledons (Pl. LXVIII, Fig. I, A). Each cotyledon consists of a long slender petiole 
bearing a large thin lamina with retuse apex. A definite midrib traverses the blade, and gives off a pair of branches before bifurcating near the apex. Thus each lobe of the cotyledon is supplied with two principal branch veins. Near the apex are ramifications of smaller vascular strands consisting solely of spiral vessels or tracheides, which end in curious cavities forming a kind of hydathode (24). The point of attachment of the seed-leaves is marked by a large swelling, but there is no cotyledonary tube.

Transverse sections of the lamina show the midrib with the lateral veins and their branches (Diagram I, Figs. I and 2). The mesophyll is differentiated into palisade tissue and spongy parenchyma, and at various points are large secretory cells with vascular connexions. Coming down the lamina the lateral strands join on to the midrib. Anastomoses occur at the junction of blade and petiole and occasionally lower down, and in the

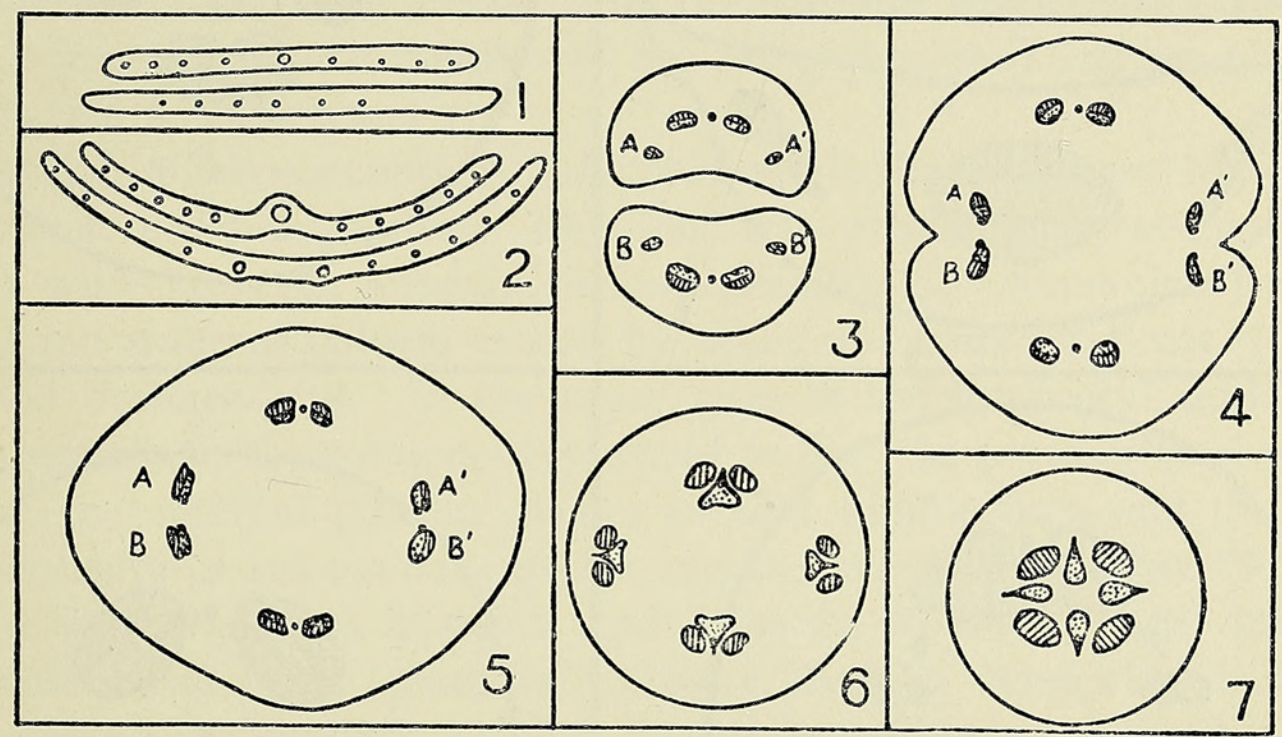

DiAgram I. Convolvulus tricolor, var. major. Transition from cotyledons to root. In Figs. 3-7 and in the following diagrams, protoxylem is shown in black, metaxylem dotted, and phloem hatched.

upper part of the latter there is a large median bundle and two small laterals, all simple and collateral in structure. While still in the petiole the median strand divides, two groups of xylem and phloem moving away right and left, leaving a small protoxylem strand between them. In this condition (Diagram I, Fig. 3) the bundles enter the hypocotyl, where the small lateral strands $\left(A\right.$ and $A^{\prime}$ ), increased in size by the appearance of metaxylem elements, move towards their fellows (B and $\mathrm{B}^{\prime}$ ) from the other cotyledon, the protoxylems turning outwards during the process (Diagram I, Fig. 4). The protoxylem groups of these bundles become detached from the metaxylem masses, and taking up a position between the latter, they fuse together, and traverse nearly the whole of the hypocotyl in this condition (Diagram I, Fig. 5). The group corresponding to the midrib, on the other hand, decreases in size, and while travelling down the hypocotyl its constituent parts assume different positions, and are not always well defined. 
During the greater part of the transition, the four vascular groups in the hypocotyl are equal in size and similar in configuration, and it is impossible structurally to distinguish between the intercotyledonary strands and those in the plane of the cotyledon. The phloem is extremely small in amount, and at no point can internal phloem be recognized with certainty-an

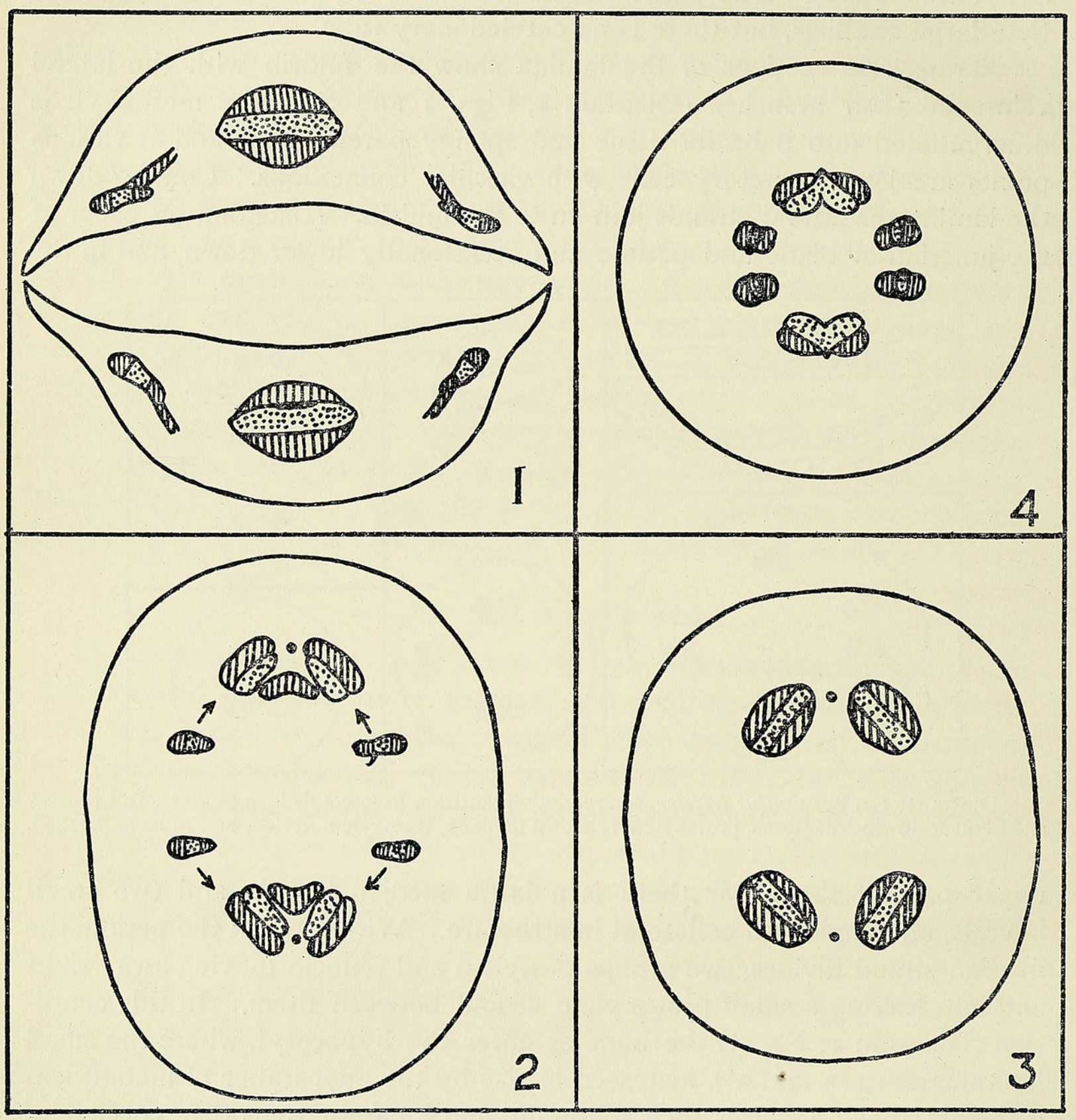

Diagram 2. Convolvulus tricolor.

observation which emphasizes the late appearance of this tissue noticed by other observers.

Finally,"the protoxylem in each case becomes definitely external, and the metaxylem groups fuse; the xylem masses move towards the centre, the corresponding phloem groups meet and fuse, and a tetrarch root is 
produced, in which the pith and endodermis are characteristic features (Diagram I, Fig. 6).

Convolvulus tricolor, L. In this example, seedlings of which were obtained after the above description had been written, one or two differences must be noted. Externally the young plants are very similar, though in C. tricolor there is a tendency to form a slight cotyledonary tube. Internally, also, the arrangements in this species and the var. major show a general similarity in the broad features. In the petiole anastomoses occur between the median bundle and the lateral ones, and often strands of phloem can be detected connecting the bundles together (Diagram 2, Fig. I). In the upper part of the hypocotyl the two lateral bundles approach the median one, and finally more or less complete fusion occurs (Diagram 2, Figs. 2 and 3). At a lower level the two lateral strands again separate, and, as in var. major, approach their fellows from the opposite cotyledons, giving rise to the intercotyledonary bundles of the tetrarch root (Diagram 2, Fig. 4, and Diagram 1, Figs. 6 and 7).

Another difference consists in the presence, in the petiole and hypocotyl, of abundant internal phloem. This fact was noted by Lamounette (12, p. 219), who, however, appears to have doubted the connexion between internal and external phloem traced by other observers (cf. Scott (18) and Scott and Brebner (19)). In the upper part of the hypocotyl, during the rearrangements in the cotyledonary strand so that the protoxylem becomes external, the internal phloem masses of that bundle fuse, and the fused mass gradually passes out between the metaxylem groups (before the latter meet to form the root bundles) and joins on to the external phloem. The same events take place at a lower level in connexion with the intercotyledonary bundles, so that finally an ordinary tetrarch root is produced.

Dangeard (5) investigated several examples belonging to the Convolvulaceae, but in most cases only a general description of the genus is given. Among others, he described the following:

$$
\begin{aligned}
& \text { Convolvulus, } \\
& \text { Calystegia, } \\
& \text { Quamoclit coccinea, } \\
& \text { Ipomoea, }
\end{aligned}
$$

all of which follow the method already given. One difference, however, must be noted. Speaking generally of the Convolvulaceae, Dangeard described the cotyledonary traces as being bicollateral in the hypocotyl. In the present research, however, nothing of the nature of internal phloem was found in any part of the seedling of $C$. tricolor, var. major.

Ipomoea versicolor, Meissn. From the description by Scott (18, 
pp. I74, I75) the transition phenomena appear to be almost exactly as described above for Convolvulus tricolor. In this case also internal phloem is present both in cotyledons and in hypocotyl. As the xylem groups of each bundle come together at the base of the hypocotyl, the corresponding phloem mass passes out between them and joins the external phloem.

Ipomoea leucantha was described by Lamounette (12, p. 220), and appears to differ from $I$. versicolor only in that 'internal' phloem is absent from the vascular bundles in the cotyledons.

Ipomoea purpurea, investigated by Gerard (7, p. $\left.3^{69}\right)$, is not essentially different from $I$. versicolor.

Cuscuta Epilinum, Weihe. Much is generally known concerning the anatomy of Cuscuta. Seedlings of various species were re-

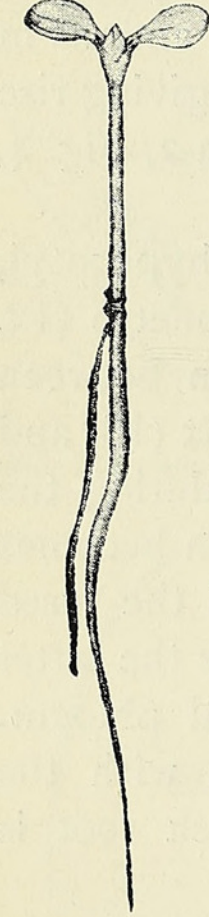

TEXT-FIG. I. Cuscuta Epilinum on Limum usitatissimum (nat. size). examined, however, in the hope that a knowledge of the seedling structure of other genera might throw some light on that of Cuscuta. Unfortunately, no new observations can be recorded. Special attention was devoted to C. Epilimum. The seedlings investigated were $2-5 \mathrm{~cm}$. in length, were quite undifferentiated, and had the appearance of a piece of fine string. In one case (Text-fig. I) the upper part twice encircled the stem of the host, and haustoria were beginning to form. Internally, most of the tissue was cortical, the vascular elements being aggregated into an insignificant axile strand. The tissue composing the latter was much reduced, and in some cases (lignification being at a minimum) it was impossible, in transverse sections, to distinguish between wood and phloem. The sieve-tube tissue occupied the periphery of the stele, and enclosed the undifferentiated vessels, in which, however, no order of development could be recognized. In the upper portion of the larger seedlings the vessels became arranged into more or less definite groups, each with a little phloem. Up to the present it has been impossible to find anything even remotely resembling transition phenomena.

\section{Polemoniaceae.}

No examples from this order were examined during the present research, but in Polemonium caevuleum, described by Gerard (7, p. 373), the transition follows Type 3. The same remark applies to

\section{Hydrophyllaceae,} of which Gerard investigated Hydrophyllum canadense (7, p. 373);

\section{Boraginaceae,}

the same worker taking Lithospermum gremil as his example $(7, \mathrm{p} .374)$; 


\section{Labiatae,}

of which two species were examined:

\section{Phlomis fruticosa \\ Galeopsis ladanum (7, pp. 379-80).}

In all these cases the seedlings were small and slender, and the transition, with certain variations, followed Type 3 . The two genera, Phlomis and Ocimum (with special reference to $O$. basilicum), were investigated by Dangeard (5), whose description agrees in all essential particulars with that of Gerard referred to above.

\section{Solanaceae.}

Nicandra physaloides, Gaert. Seedlings very small; cotyledons shortly stalked, equal in size, and comparatively fleshy. There is no cotyledonary

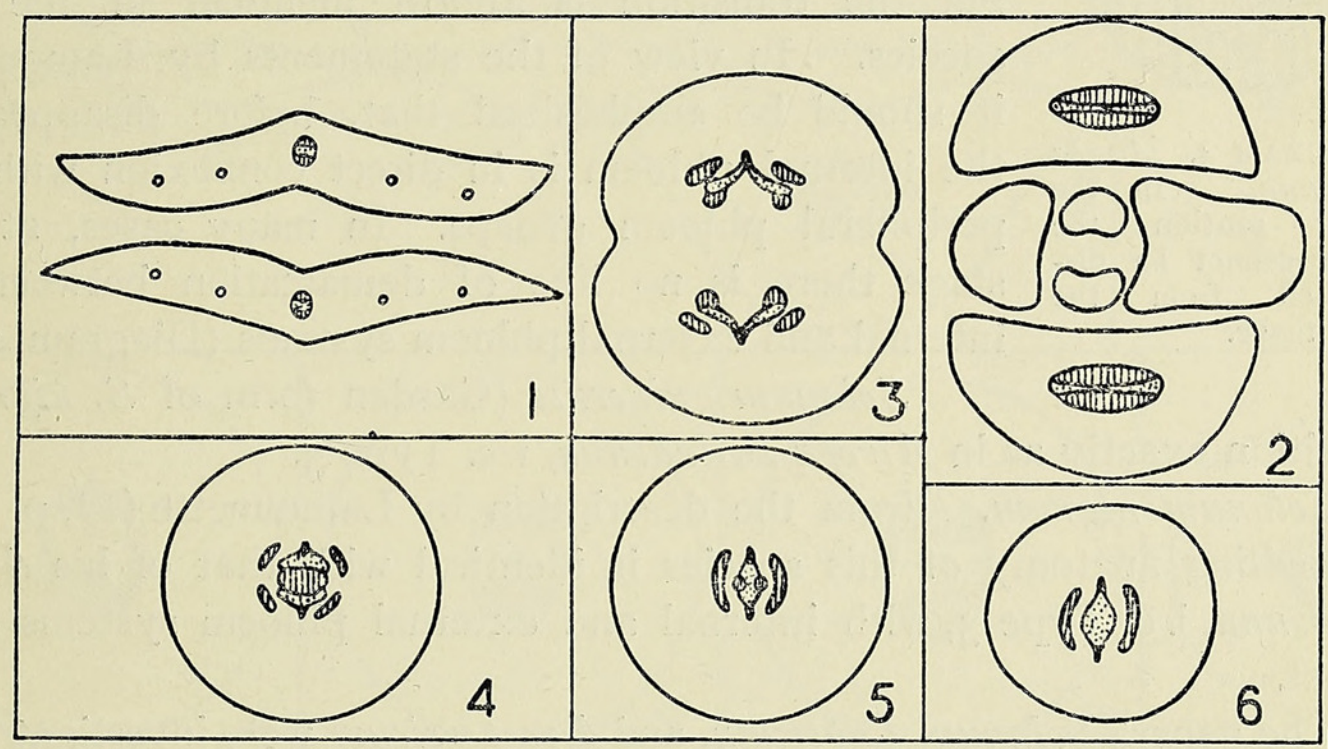

Diagram 3. Nicandra physaloides.

tube. The various aerial parts are covered with the pedicellate glandular hairs characteristic of the Solanaceae.

The lamina is traversed by a rather large vascular strand which gives off numerous small branches (Diagram 3, Fig. I). Near the base of the cotyledon this midrib consists mostly of phloem, arranged on the upper and lower sides of a flattened strand of tracheae, of which the middle ones represent the protoxylem (Diagram 3, Fig. 2). As the strand enters the hypocotyl the internal and external phloem groups bifurcate, and at the same time the protoxylem becomes definitely exarch (Diagram 3, Fig. 3) by moving outwards in the cotyledonary plane. At this stage there are two strands of xylem with eight phloem groups, four of which are internal, the remaining and much larger groups being peripheral and situated on diagonal lines. Rearrangements continue to go on gradually; the vascular groups 
close in towards the centre, the pith disappears, and the xylem strands are only separated by the internal phloem masses, which have now fused together (Diagram 3, Fig. 4). Finally, a large trachea appears in the centre connecting the two xylem masses, and dividing the internal phloem into two parts (Diagram 3, Fig. 5) which pass out right and left and join on to the external phloem. The simple diarch condition seen in Diagram 3 , Fig. 6 , is thus obtained; and the transition is according to Type 3 of Van Tieghem.

Atropa Belladonna, L. This species was also investigated by Gerard ( 7, p. 377$)$ and by Lamounette $(12$, p. $21 \mathrm{I})$. The latter, however, described the internal phloem as being quite distinct from the

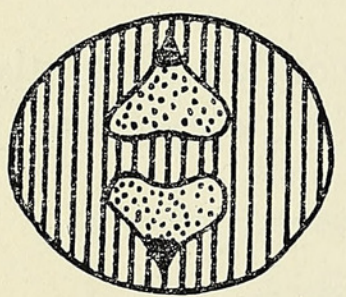

Diagram 4. Atropa Belladonna. In the hatched portion the phloem cannot be distinguished from the ground tissue. external phloem even at the base of the hypocotyl. The present observations agree with those of Gerard. The seedlings are larger than in Nicandra physaloides, but the transition is almost identical in the two species. In view of the statements by Lamounette it should be emphasized that, before disappearing, the internal phloem is in direct connexion with the peripheral phloem groups. In many cases, at one stage there is no line of demarcation between the internal and external phloem systems (Diagram 4).

Solanum guineense (Garden form of S. nigrum). Transition exactly as in Atropa Belladonna, i. e. Type 3.

Solamum nigrum. From the description by Lamounette (12, p. 2II), the seedling anatomy of this species is identical with that of his Atropa Belladonna, i. e. Type 3 , with internal and external phloem systems quite distinct.

The genera Solamum, Capsicum, and Lycopersicum were investigated by Dangeard (5), and in the main the transition resembles that given above for Atropa Belladonna.

Datura Stramonium, L. This species was first investigated by Gerard ( 7, p. 37.5), with whose description the following agrees, except in one or two details. The genus was also generally referred to by Lamounette (12, p. 2II).

The fairly large seedling has two fleshy, slightly unequal cotyledons, with swelling at point of attachment, but without any signs of a cotyledonary tube. The lamina, which passes gradually into the short petiole, has a definite midrib with slender branches which end near the periphery of the leaf. The mesophyll shows the usual differentiation.

In the lamina the midrib consists of a triangular mass of tracheae with the protoxylem at the upper apex, surrounded by phloem, the upper (" internal') part of which disappears near the apex of the cotyledon. All except the smallest branches are bicollateral in structure (Diagram 5, Fig. I). 
At the base of the lamina, often only a single bundle is present. In this strand, rearrangements begin in the upper part of the petiole, by the disappearance of the phloem elements from the sides simultaneously with the lateral elongation of the xylem. Almost immediately the lower ("external') phloem bifurcates, and traverses the remaining part of the petiole and the hypocotyl as two distinct groups (Diagram 5, Fig. 2).

In some cases the rearrangement of the xylem results in the production of three masses-a small median strand of protoxylem, and two lateral strands consisting chiefly of metaxylem, in which protoxylem elements can be distinguished for some distance. Even in the clearest cases, these

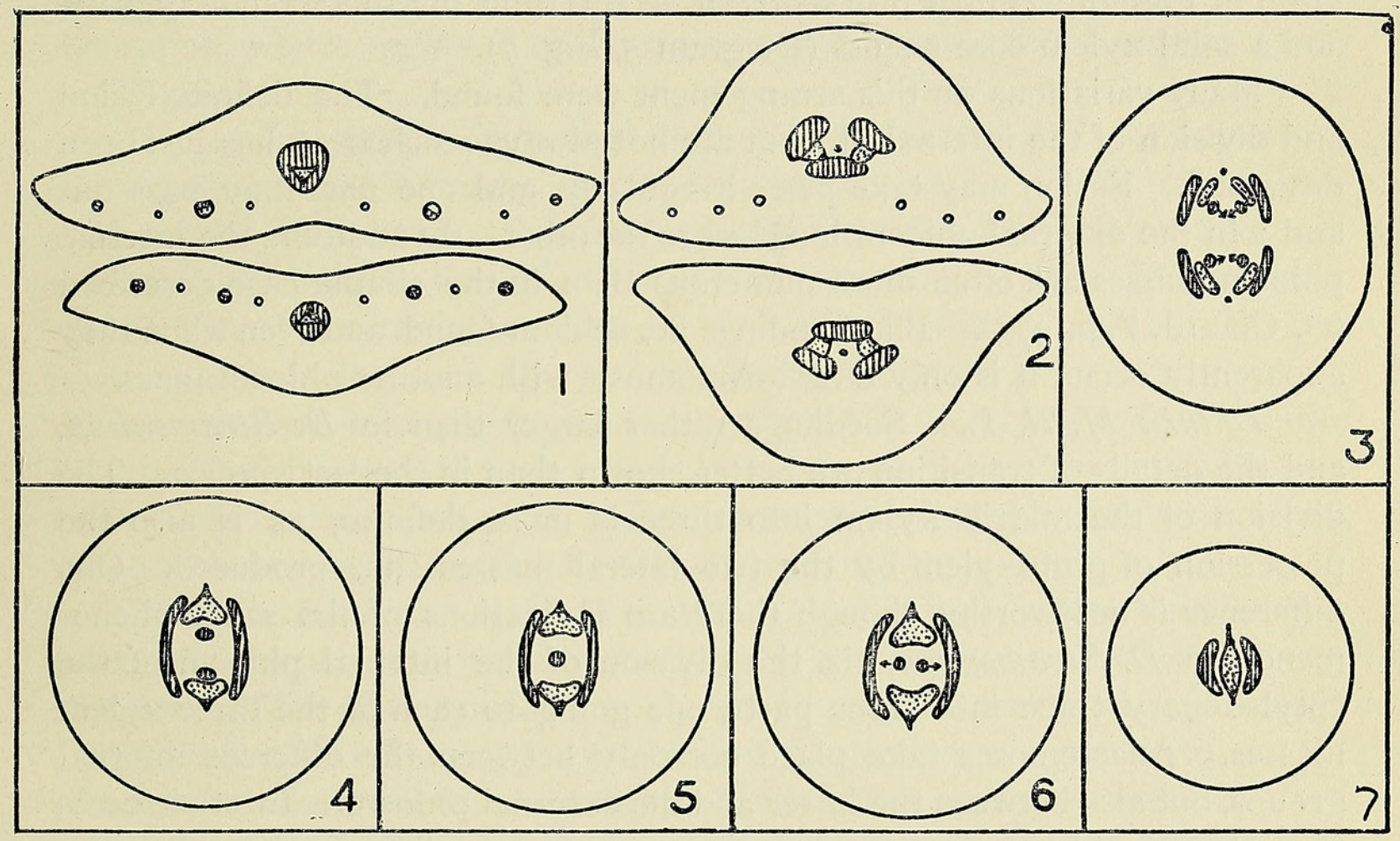

DiAgram 5. Dalura Stramonium.

lateral protoxylem groups disappear after a longer or a shorter course, while in other examples the only definite protoxylem is the median one. The lateral xylem groups diverge, and take with them the corresponding external phloem mass and also part of the internal phloem, and further rearrangement in the upper region of the hypocotyl results in the production of the structure shown in Diagram 5, Fig. 3.

Further changes are due to the closing in of the various tissues. Each external phloem mass joins its fellow from the opposite cotyledon; the whole of the xylem derived from each cotyledonary bundle moves towards the centre of the hypocotyl, and at the same time the metaxylem strands of each bundle fuse and take up a position internal to their respective protoxylems (Diagram 4, Fig. 4). Finally, the two xylem bundles meet at the centre, and a typical diarch plate results (Diagram 4, Fig. 5). 
The behaviour of the internal phloem groups is interesting. While still in the petiole, the internal phloem undergoes equal division, one part going to each of the lateral xylem masses. In these positions, and with occasional anastomoses, the whole of the hypocotyl is traversed. Previous to entering the root, however, the two groups belonging to one midrib come together and fuse (Diagram 5, Fig. 4); then, passing to the centre, they join on to the group derived from the other cotyledon (Diagram 5, Fig. 5). Occasionally, anastomoses with the external phloem are seen. Finally, the fused phloem mass elongates in the intercotyledonary plane, bifurcates, and the two branches pass out right and left to join the external phloem (Diagram 5, Fig. 6). A little pith is present at this time, but this soon disappears, and a solid xylem core results (Diagram 5, Fig. 7).

Many variations on this arrangement were found. The definite fusion and division of the internal phloem are not always so clear as has just been described. Fusion may take place irregularly, and one part may pass out and join the external phloem long before the other. In addition, the internal phloem masses are often more numerous than in the simple case described (cf. Gerard, 7, p. 375). Blind endings are seldom found, and even when they apparently occur, it is only after anastomosis with another phloem mass.

Datura Metel, L. Seedlings rather larger than in D. Stramonium, and the details of transition are better shown than in the last species. The division of the midrib xylem into three is more definite, as is also the possession of protoxylem by the two lateral masses thus produced. One difference is noteworthy, though there are indications of the same phenomenon in D. Stramonium, viz. the division of the internal phloem of the cotyledonary trace into three parts, one going to each of the three xylem masses. Anastomoses take place not only between the different internal groups, but also between the latter and the external phloem. In other cases the internal phloem groups were more numerous. The final result is the same; all the internal phloem masses come together in the centre, the fused bundle divides, and the two parts diverge and join the peripheral phloem. Another peculiarity was seen in one specimen in which the three protoxylem groups derived from one cotyledonary bundle remained distinct for a long time after the root was reached (Pl. LXVIII, Fig. 2). The lateral protoxylems were at first stronger, but after a time they decreased in size and finally disappeared. The metaxylem became more compact, and the median protoxylem assumed the exarch position in the plane of the cotyledons.

Nicotiana alata, Link and Otto. In this species the seedlings are very small, and the transition, which takes place in the upper part of the hypocotyl, is according to Type 3. This species differs from the rest of the Solanaceae examined in the scanty supply of phloem, this tissue being entirely absent from the inner side of the vascular bundle, which, therefore, throughout the 
cotyledons and hypocotyl, are of the collateral type. Lamounette (12, p. 2II), on the other hand, describes the genus Nicotiana as being like Solanum nigrum, in which internal phloem is present.

Salpiglossis simuatus, Hook. The seedlings of this species are very minute, and even in the smallest the transition phenomena are obscured by the presence of secondary thickening. The chief features, however, appear to be similar to those described for Nicandra physaloides.

Petunia violacea, Lind. Seedlings very small, cotyledons slightly unequal, with trace of cotyledonary tube. The poorly developed vascular tissue suggests that the seedlings are immature, a condition which probably accounts for the absence (as in Nicotiana alata) of internal phloem. The transition, which begins in the petiole, is quickly completed, and conforms to Type 3 .

Browallia viscosa, H.B. and Kth. This species was not examined during the present research. From the description by Scott and Brebner (18, p. 267) the transition is according to Type 3 , but differs from the plants already described in the behaviour of the internal phloem. In the upper part of the hypocotyl there are 10-I 2 internal phloem masses. Passing down towards the root the pith gradually disappears, and the internal phloem strands successively pass out between the converging xylem bundles and one by one reach the external phloem strands. The two xylem bundles unite to form the diarch plate, and at this point the last of the internal phloem strands passes out and joins the normal phloem.

Schizanthus pinnatus, Ruiz. et Pav. Seedlings not more than a centimetre in length, and on the whole, both externally and internally, very similar to Nicandra physaloides. A few minor differences may be noted. The small epicotyledonary strands, two in number and arranged in the intercotyledonary plane, are peculiar in that they persist down to the base of the hypocotyl, the xylem groups especially remaining quite distinct until they fuse with the root bundles just as the latter approach to form the diarch plate. The xylem of the cotyledonary traces is rather irregularly disposed, a condition which is emphasized by the presence of intercellular spaces near the two protoxylems. The preliminary rearrangements which the internal phloem groups undergo are similar to those in Nicandra physaloides; but after fusion in the centre and subsequent division, the two phloem masses appear to die out instead of merging into the external phloem. With the disappearance of the last remnants of the pith, the two xylem bundles become continuous, and a diarch root is produced.

Nierembergia gracilis, Hook. Apart from the slightly larger size of the seedlings this species resembles Schizanthus pinnatus in all particulars. In one seedling, in which the primary tissues in the hypocotyl were not fully developed, there was scarcely a trace of 'internal' phloem in the cotyledons; while in another, whose hypocotyl showed much secondary 
wood, the midrib of the seed-leaf was conspicuously bicollateral in structure. In all cases the transition was according to Type 3 , and the internal phloem died out in the root.

\section{Scrophulariaceae.}

Verbascum pulverulentum, Vill. Seedlings about two centimetres long, with definite hypocotyl and two unequal cotyledons. Each cotyledon consists of a large lamina which passes gradually into the definite petiole. There is no cotyledonary tube.

In the lamina the midrib sends out small branches, but enters the petiole as a single rather small vascular bundle. The rearrangement of the vascular tissue begins before the strand enters the hypocotyl, and is completed very quickly. The transition, which is according to Type 3 , is masked by the presence of two epicotyledonary traces situated in the intercotyledonary plane, which persist throughout the hypocotyl and enter the root. Thus for a long distance in the upper part of the root the arrangement appears to be tetrarch when it is really diarch, a condition which is indicated by the origin of the lateral rootlets. These are given off in four rows from the two ends of the diarch plate.

Alonsoa. As described by Dangeard (5) the transition in this genus appears to conform to Type 3 .

Diascia Barberae, Hook. In most Scrophulariaceae examined, the rearrangement of the vascular tissue begins in the upper part of the petiole, and one of the first indications is the separation of the xylem strand into three more or less definite portions, of which the median one is the protoxylem. In $D$. Barberae the xylem remains throughout quite continuous. In the upper part of the petiole, the vascular bundle divides into two parts (Diagram 6, Figs. I and 2) connected towards the upper surface by means of protoxylem elements. Each semi-strand possesses its own phloem mass. The transition takes place by the passage of the phloem groups to a position in the intercotyledonary plane, where they fuse with their fellows from the other seed-leaf, and by a simple twisting on the part of the xylem, so that the protoxylem takes up an external position (Diagram 6, Fig. 3).

Linaria origanifolia, DC.

Linaria heterophylla, Desf.

In both species the minute seedlings are provided with two equal petiolate cotyledons. There is no cotyledonary tube.

The transition, which is according to Type 3 , commences in the petiole, and takes place very quickly.

Nemesia floribunda, Lehur.

Nemesia versicolor, E. Mey.)

With the exception of their larger size, the seedlings of these species are exactly like those of Linaria. The method of transition is the same, and the rearrangements take place in the upper part of the hypocotyl. 
Antirrhinum Orontium, L., differs from Linaria externally only in the larger size of the seedlings and the slight inequality of the cotyledons. The region of transition is, on the whole, rather shorter; in the root the xylem plate is quite inconspicuous.

Scrophularia nodosa, L., in all essentials resembles Linaria origanifolia. In the petiole the xylem elements are arranged in a single row parallel with the upper surface of the leaf, while the diarch plate also consists of a single row of elements, but arranged in the cotyledonary plane.
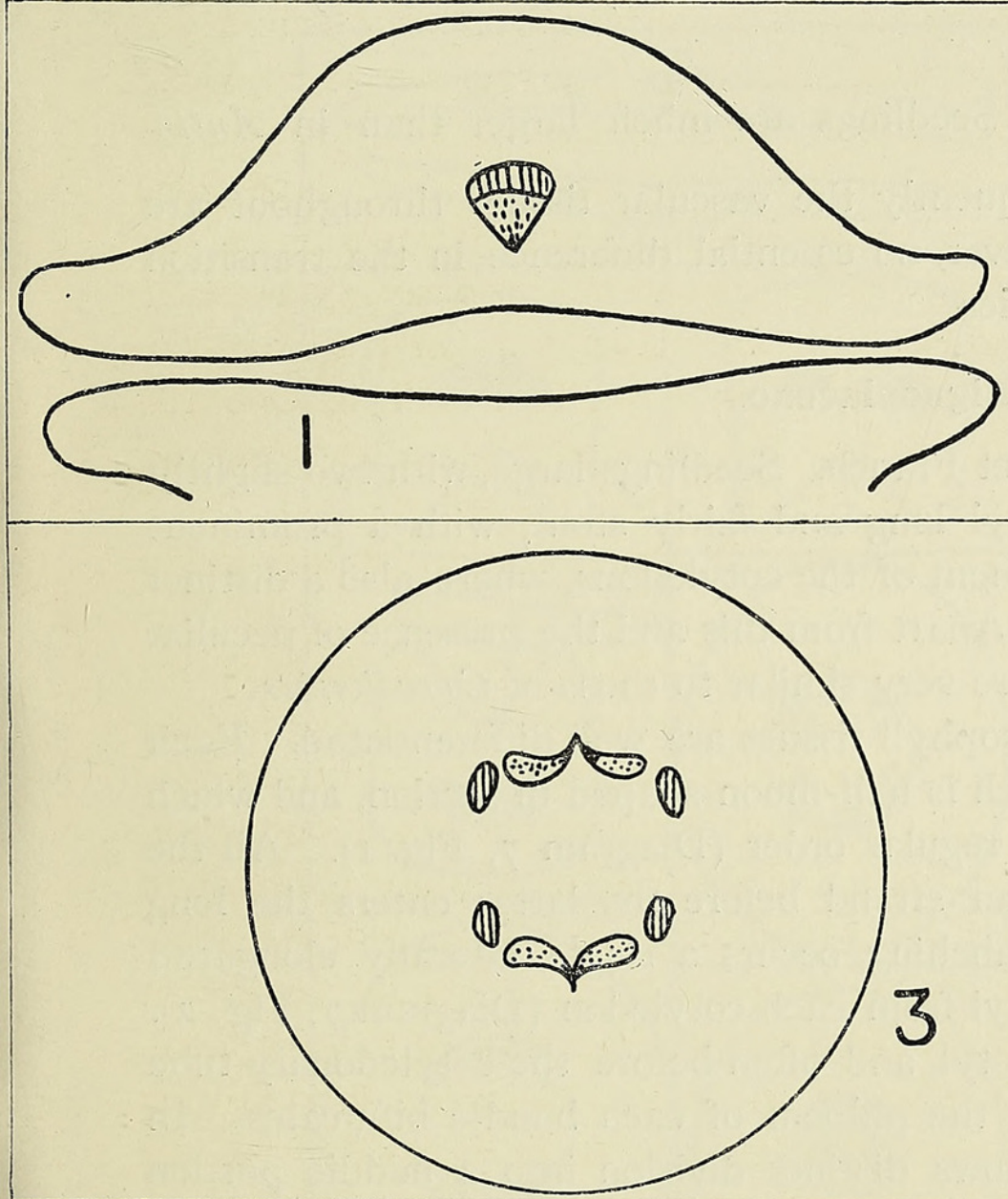

Diagram 6. Diascia Barberae.

Torenia asiatica, L.

Torenia Fournieri, Linden. $\}$ In both species the transition is according to Type 3, and resembles that of Antirrhinum Orontium in all respects.

Mimulus luteus, L. Apart from the presence of a cotyledonary tube, the seedlings of this species, both externally and internally, are very similar to those of Antirrhinum Orontium.

Dischisma arenarium, E. Mey. Seedlings small, with narrow, rather fleshy cotyledons which form a slight tube at point of attachment. The rearrangements, which are according to Type 3 , take place as in 
Antirrhinum Orontium, but the region of transition is shorter, and is confined to the upper part of the hypocotyl.

Tetranema mexicanum, Benth. As in Mimulus huteus.

Zaluzianskya capensis, Walp. Seedlings differ in no respect from those of Mimulus huteus.

Veronica longifolia, L.

Veronica hederaefolia, L. (also described by Gerard (7, p. 378)). Exactly similar to Mimulus luteus.

Rehmannia angulata, Hemsl. Both externally and internally similar to Linaria origanifolia.

Digitalis ferruginea, L.

Digitalis lanata, Ehrh. $\}$ Seedlings are much larger than in Antirrhinum Orontium, and consequently the vascular tissues throughout are more definite. There is, however, no essential difference in the transition phenomena of these three species.

\section{Bignoniaceae.}

Incarvillea Delayvei, Bur. et Franch. Seedlings large, with two slightly unequal cotyledons. Hypocotyl long and fairly stout, with a prominent swelling at the point of attachment of the cotyledons, where also a distinct cotyledonary tube is formed. Apart from this and the presence of peculiar glandular hairs, the seedlings are very similar to those of Convolvulus.

In the seed-leaves the mesophyll tissues are well differentiated. Each lamina has a large midrib, which is half-moon-shaped in section, and which gives off numerous branches in regular order (Diagram 7, Fig. I). All the branches fuse with the median strand before the latter enters the long petiole, and as no further branching occurs a single laterally elongated bundle passes into the hypocotyl from each cotyledon (Diagram 7, Fig. 2). Previous to entering the hypocotyl, and often before the cotyledonary tube is reached (Diagram 7, Fig. 3), the phloem of each bundle bifurcates. In some cases also, the xylem shows distinct division into a middle portion consisting of protoxylem, and two lateral parts in close connexion with the phloem groups, and consisting of metaxylem with a few protoxylem elements (Diagram 7, Fig. 2a). This condition, interesting for comparison with other species, is not constant ; it was found in one specimen, and even there did not persist for very long. In all cases, in the upper part of the hypocotyl, there are two bundles of xylem each with a single protoxylem group (Diagram 7, Fig. 4), and the rearrangements that now occur take place very gradually. As each bundle passes down the hypocotyl, its protoxylem divides into three, each branch at first consisting of $\mathrm{I}-3$ elements (Diagram 7, Fig. 5, and Pl. LXVIII, Fig. 3). The middle one passes almost directly outwards and takes up an exarch position in the plane of the cotyledons. The lateral groups traverse an oblique path, and finally come 
to rest near the periphery of the stele in the intercotyledonary plane, where each one fuses with its fellow from the other seed-leaf bundle (P1. LXVIII, Fig. 5). There are thus formed four protoxylem groups, of which the two in the cotyledonary plane are much the stronger, and in these the metaxylem closes in behind so that typical root bundles are produced. At a lower level metaxylem also appears on the inner side of the other protoxylem groups, and a tetrarch root results, in which the metaxylem always preponderates in the intracotyledonary strands (Diagram 7, Fig. 6). No other condition was found in any root.

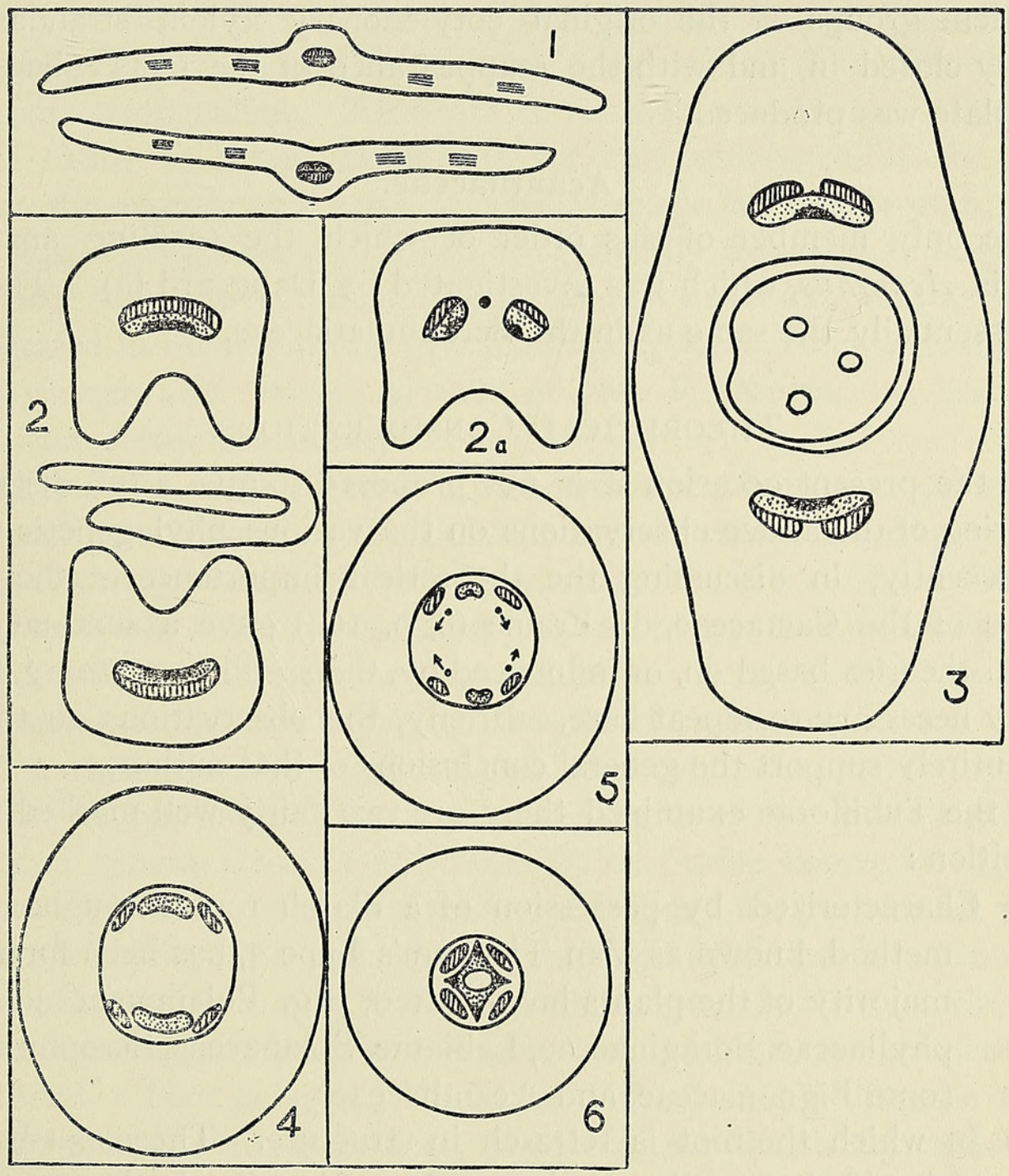

Diagram 7. Incarvillea Delayvei.

It is to be noted that the transition in this species is remarkably like that of Anemarrhena (13), in both of which a tetrarch root structure is obtained from two cotyledonary traces. This type of transition has hitherto been found, among dicotyledons, only in certain Cactaceae (6), and possibly in Eranthis and Podophyllum.

Eccremocarpus scaber, Ruiz. et Pav. Only a single seedling of this species was available. This specimen was much smaller than those of Incarvillea Delayvei, and resembled the latter in no particular. The 
cotyledons were petiolate, retuse, and markedly unequal. A number of small veins supplied the lamina, and these were collected at the base into a single bundle which entered the petiole. The transition, slightly obscured by the presence of secondary thickening in the hypocotyl, was of Type 3, and began in the petiole. In the shorter petiole, the protoxylem became external by simple rearrangement of the xylem elements. In the other the xylem divided into three portions, the median one (protoxylem) taking up an external position. The metaxylem in both cases moved towards the centre, became fragmentary, and finally disappeared, leaving only the protoxylem groups of the original cotyledonary xylem strands. These gradually closed in, and with the reappearance of the metaxylem a small diarch plate was produced.

\section{Acanthaceae.}

The only member of this order of which the seedling anatomy is known is Acanthus, which was investigated by Dangeard (5). The transition is essentially the same as in the Scrophulariaceae.

\section{Theoretical Considerations.}

On the present occasion it is not proposed to give a full discussion of the bearing of the above observations on the various phylogenetic theories. Quite recently, in discussing the theoretical importance of the seedling structure of the Cactaceae, de Fraine (6, p. I64) gave a summary of the principal theories based on, or influenced by, the seedling anatomy, which it is hardly necessary to repeat here. Briefly, the observations on the Tubiflorae entirely support the general conclusions of that author.

In the Tubiflorae examined there are two fairly well marked methods of transition:

(I) Characterized by possession of a diarch root throughout. This method, known as Van Tieghem's Type 3, has been found in the majority of the plants investigated, e.g. Polemoniaceae, Hydrophyllaceae, Boraginaceae, Labiatae, Solanaceae, Scrophulariaceae, some Bignoniaceae, and Acanthaceae.

(2) In which the root is tetrarch in structure. These can be further classified according to the number of bundles in the upper part of the hypocotyl.

(a) In the Convolvulaceae, a 'double' midrib and two small lateral bundles enter the hypocotyl from each cotyledon and become orientated to produce the tetrarch root. This is obviously merely a modification of Van Tieghem's Type 2.

(b) In some Bignoniaceae (e. g. Incarvillea Delayvei) a single bundle enters the hypocotyl from each cotyledon, where it undergoes division and orientation which result in the production of a tetrarch root structure. 
The great majority of the species comprised in the Tubiflorae are herbaceous, and in many respects this extensive group is generally regarded as a remarkably natural one. Engler and (especially) Bentham and Hooker recognized certain sub-groups; and in the latest attempt to deal with the Tubiflorae, Wernham (29), discussing the question from the point of view of floral evolution, appears to hold that certain of these sub-groups are not only well defined, but possibly had a quite different course of evolution. In this connexion, it is perhaps worthy of note that in the principal sub-groups, i. e. in Polemoniales, Personales, and Lamiales of Bentham and Hooker, the prevailing method of transition is Type 3, while in each of the groups Polemoniales and Personales a single Natural Order shows (in part) a different arrangement. Although it is not possible to advance any external cause as being responsible for this difference in the seedling anatomy, the cases quoted serve to emphasize the fact that orders, and even genera (e.g. of Bignoniaceae) which are generally regarded as being closely allied, show different methods of transition. Conversely, just as de Fraine demonstrated in the delimiting of Cactaceous genera, so here with regard to the sub-groups and (rarely) orders of the Tubiflorae, no assistance is derived from seedling anatomy.

Perhaps the chief interest which emanates from the present study of the seedling structure or the Tubiflorae attaches to the occurrence of the Anemarrhena type of transition. Previous to the discovery of this type in the Cactaceae (6), it had been found only in certain Ranunculaceae among dicotyledons $(13,17)$, and on its occurrence here, as well as on other features common to this order and to certain monocotyledons, had been founded a theory of the origin of the latter group from a dicotyledonous ancestor. In opposing this view to the light of her discoveries in the Cactaceous genera, Opuntia and Nopalia, de Fraine concludes (6, p. I67): 'It cannot be considered that the resemblance of Opuntia, for example, to Anemarrhena is the result of a close genetic relation between the two ; nor can it be conceded that it is due to the response of two unrelated forms to similar conditions; hence we cannot but conclude that the resemblance is accidental. This being so, then it is quite possible that the similarity of Eranthis and Podophyllum to Anemarrhena is also accidental.' The conclusion arrived at is that "the evidence on which the "fusion" hypothesis [of Sargant (14)] was based has been considerably weakened by the discovery of the Anemarrhena type of seedling in such a specialized order as the Cactaceae'.

This conclusion, however, is not generally admitted. It has been called into question by (Mrs.) A. Arber (1) on the ground that the Cactaceae, while showing a high degree of specialization in their vegetative characters, may really be closely ailied to the Ranales. A comparison was made between the floral structures in the two orders, Nymphaeaceae and 
Cactaceae, the writer inclining to the view that the two groups 'are derived from the same ancestral stock', and that 'it is no longer necessary to look upon [the occurrence of the Anemarrhena type in the Cactaceae] as accidental. Among the Cactaceae this type of transition occurs in those genera whose seedlings are least modified, and it is in such cases that we should naturally expect to find that ancestral characters had been retained.' The conclusion of A. Arber is 'that Miss Sargant's view that the various monocotyledonous and dicotyledonous types of seedling anatomy were all originally derived from the Anemarrhena type is strengthened, rather than weakened, by the discovery of the ancestral type among the Cactaceae.'

In making this criticism the writer admits that the question depends very largely upon the systematic position of the group in question. The force of the criticism is, in fact, proportionate to the real distance between the Cactaceae and the group from which it was derived, which is assumedan assumption that is itself not unquestioned-to have given origin also to the Nymphaeaceae and the other members of the Ranalian plexus. If, therefore, there exists a group which shows specialization in the 'parts of prime importance as regards affinities', i. e. 'in the reproductive organs, and not the vegetative features of the mature plant', and which also possesses the Anemarrhena type of seedling structure, it will perhaps be conceded that some ground exists for the view that the resemblance between the seedlings of this group and those of Eranthis, \&c., is accidental. Such a state of affairs is found in the Bignoniaceae. Even assuming that this order was originally derived from the same group as the Ranales, there can be no doubt as to the want of affinity between the two, and that any character which is common to Incarvillea Delayvei (Bignoniaceae) and the Ranales serves to indicate nothing more than an analogy, and is, to use de Fraine's term, quite 'accidental'. Neither can there be any reasonable doubt that the discovery of the Anemarrhena type in this highly evolved group has not only 'considerably weakened the evidence on which the "fusion" hypothesis was based', but also has placed 'Sargant's view that the various monocotyledonous and dicotyledonous types of seedling anatomy were all originally derived from the Anemarrhena type' beyond the region of probability.

It is highly probable that many other species, more or less remote from the Ranunculaceae or Liliaceae, will be found to possess the Anemarrhena type of seedling anatomy. The observations on Convolvulus recorded above indicate the absence of any sharp line of demarcation between the Anemarrhena method and Van Tieghem's Type 2. What is practically the latter is seen in Convolvulus tricolor, var. major. If, in this example, the lateral cotyledonary strands fused with the median one, and, at a lower level, separated and became orientated to form the tetrarch root, the Anemarrhena type, with, however, two cotyledons instead of one, would 
be obtained. As a matter of fact, this sequence is found to occur in Convolvulus tricolor, which, therefore, serves to connect Type 2 with the Anemarrhena type.

\section{SUMMARY.}

I. The present paper deals with the seedling anatomy of the following Natural Orders of the Tubiflorae: Convolvulaceae, Polemoniaceae, Hydrophyllaceae, Boraginaceae, Labiatae, Solanaceae, Scrophulariaceae, Bignoniaceae, and Acanthaceae.

2. Much variation occurs in the size of the seedlings belonging to different species. Broadly speaking, in the smaller seedlings the transition region is short, and the rearrangements are concluded in the upper part of the hypocotyl; while in the larger seedlings the region of transition is very extended (cf. Compton (4)).

3. Cotyledons invariably two in number, and while the members of each pair are often unequal in size, this apparently has no effect on the essential transition phenomena.

4. Cotyledonary tubes are present in members of all the orders examined, but their presence appears to have no bearing on the type of transition. Nearly related species having the same type of seedling structure show marked differences with regard to the cotyledonary tube.

5. The prevailing type of transition, which is present in all the smaller seedlings, is Van Tieghem's Type 3, and occurs in Polemoniaceae, Hydrophyllaceae, Boraginaceae, Labiatae, Solanaceae, Scrophulariaceae, some Bignoniaceae, and Acanthaceae. The larger seedlings possess a tetrarch root. In Convolvulus tricolor, var. major, the transition is a modification of Van Tieghem's Type 2, while the Anemarrhena type exhibited by Incarvillea Delayvei is approached through Convolvulus tricolor.

6. Internal phloem is present in all Solanaceae and Convolvulaceae examined with the exception of Convolvulus tricolor, var. major, Nicotiana alata, Petunia violacea, and Nierembergia gracilis (one seedling). Indications are not wanting that the absence of internal phloem in these species is owing to the incomplete development of the tissues in the specimens examined.

\section{BIBLIOGRAPHY.}

1. Arber, A.: The Cactaceae and the Study of Seedlings. New Phytologist, I910, p. 333.

2. Chauveaud, G.: L'appareil conducteur des plantes vasculaires et les phases principales de son évolution. Ann. Sci. Nat. (Bot.), $9^{\mathrm{e}}$ sér., t. xiii, I9 I I, p. I I 3 .

3. Clos, D.: Du collet dans les plantes. Ann. Sci. Nat. (Bot.), $3^{\text {e }}$ sér., t. xiii, 1849, p. 5 .

4. Compton, R. H. : Seedling Structure in the Legumincsae. (Read at general meeting of Linnean Society, Feb. I 5, IgI 2.)

5. Dangeard, P. A. : Recherches sur la mode d'union de la tige et de la racine chez les Dicotylédones. Le Botaniste, 1889 , p. 75 . 
6. DE Fraine, E.: The Seedling Structure of certain Cactaceae. Annals of Botany, xxiv, I9Io, P. I25.

7. GÉrard, R. : Recherches sur le passage à la tige. Ann. Sci. Nat. (Bot.), $6^{e}$ sér., t. xi, I 88I, p. 279.

8. Hill, A. W.: Morphology and Seedling Structure of the Geophilons Species of Peperomia. Annals of Botany, xx, 1906, p. 395 .

9. Hiı.L, T. G. : On the Seedling Structure of certain Piperales. Annals of Botany, xx, I906, p. I6 I .

10. - and DE Fraine, E.: On the Seedling Structure of Gymnosperms. Annals of Botany, xxii, 1908 .

11.

: On the Seedling Structure of certain Centrospermae. Annals

of Botany, xxvi, I9I 2, p. I 75 .

12. Lamounette, M.: Recherches sur l'origine morphologique du liber interne. Ann. Sci. Nat. (Bot.), $7^{\mathrm{e}}$ sér., t. xi, I 890, p. 193 .

13. Sargant, E.: A New Type of Transition from Stem to Root in the Vascular System of Seedlings. Annals of Botany, xiv, I900, p. 633 .

14. - The Origin of the Seed-leaf in Monocotyledons. New Phytologist, i, 1902, p. 197.

15. : A Theory of the Origin of Monocotyledons. Annals of Botany, xvii, I903, p. I.

16. - Evolution of Monocotyledons. Bot. Gaz., xxxvii, I904, p. 325 .

17. - Reconstruction of a Race of Primitive Angiosperms. Annals of Botany, xxii, I 908 , p. I 21 .

18. Scotт, D. H.: On Some Points in the Anatomy of Ipomoea versicolor, Meissn. Annals of Botany, v, I890-I, p. I 74 .

19. - and Brebner, G. : On Internal Phloem in the Root and Stem of Dicotyledons. Annals of Botany, v, I890-I, p. 259.

20. Sterckx, R.: Recherches anatomiques sur l'embryon et les plantules dans la famille des Renonculacées. Mém. Soc. Roy. Sci. Liége, $3^{\text {e }}$ sér., t. ii, 1900.

21. Tansley, A. G., and Thomas, E. N. : Root Structure in the Central Cylinder of the Hypocotyl. New Phytologist, I904.

22.

The Phylogenetic Value of the Vascular Structure of Spermophytic Hypocotyls. Brit. Ass. Report, I906.

23. Thomas, E. N.: A Theory of the Double Leaf-trace founded on Seedling Structure. New Phytologist, vi, $1907, \mathrm{p} .77$.

24. Turnbull, R. : Preliminary Note on the Distribution and Structure of Water-pores on Cotyledons. Annals of Botany, iii, I889-90, p. I23.

25. Van Tieghem, P. : Recherches sur la symétrie de structure des plantes vasculaires. Compt. Rend. Ac. des Sci., t. lviii, I869.

26. : Recherches sur la symétrie, \&c. Ann. Sci. Nat. (Bot.), $5{ }^{\text {e }}$ sér., t. xii, I87 I.

27. - Traité de Botanique, $2^{\mathrm{e}}$ éd., t. i, I89I, p. 782.

28. Vuillemin, P.: Tige des Composées. Paris, i884.

29. Wernham, H. F. : Floral Evolution, \&c. Part II, Tubiflorae. New Phytologist, Nov. ard Dec. I9II, p. 293.

\section{EXPLANATION OF FIGURES IN PLATE LXVIII.}

Illustrating Mr. Lee's paper on the Seedling Anatomy of the Tubiflorae.

Fig. I. Convolvulus tricolor, var. major. A, whole seedling ( $\frac{1}{2}$ nat. size). B, single cotyledon nat. size).

Fig. 2. Datura Metel. Portion of transverse section of upper part of root, showing three protoxylem groups. $\left(x, y, z\right.$ and $\left.x^{\prime}, y^{\prime}, z^{\prime}\right)$ in each xylem strand.

Fig. 3. Incarvillea Delayvei. Transverse section of hypocotyl, showing division of the protoxylem of each cotyledonary bundle into three ( $m . p x, l . p x a, l . p x b$, and $m . p x^{\prime}, l \cdot p x a^{\prime}, l \cdot p x b^{\prime}$, respectively). For description see text (p. 740). ph. = phloem.

Fig. 4. Incarvillea Delayvei. Transverse section of root, showing tetrarch structure derived from condition seen in Fig. 3 . 
Arrials of Botany,

Vol. XXVI PZ.IXVIII.

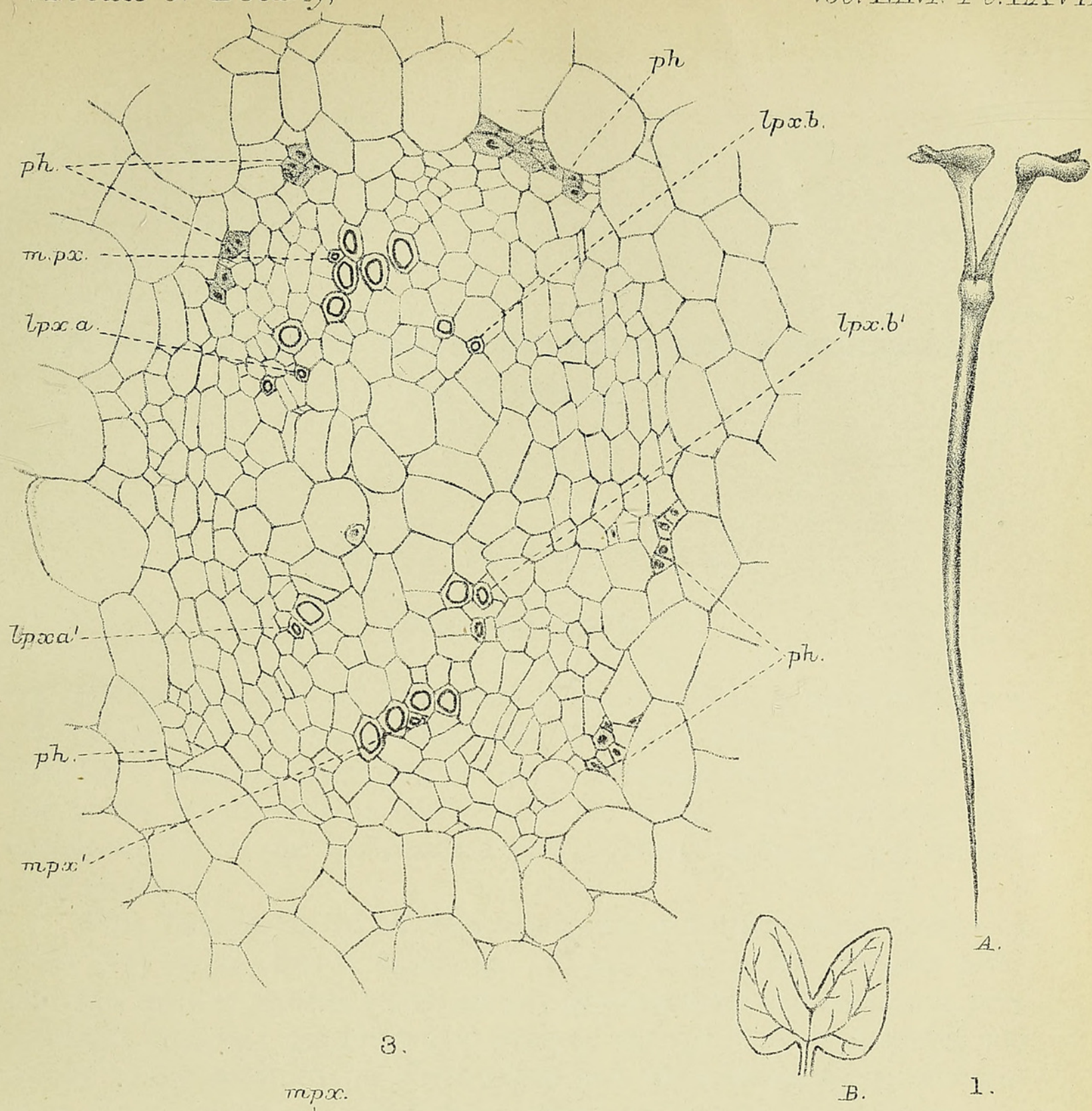

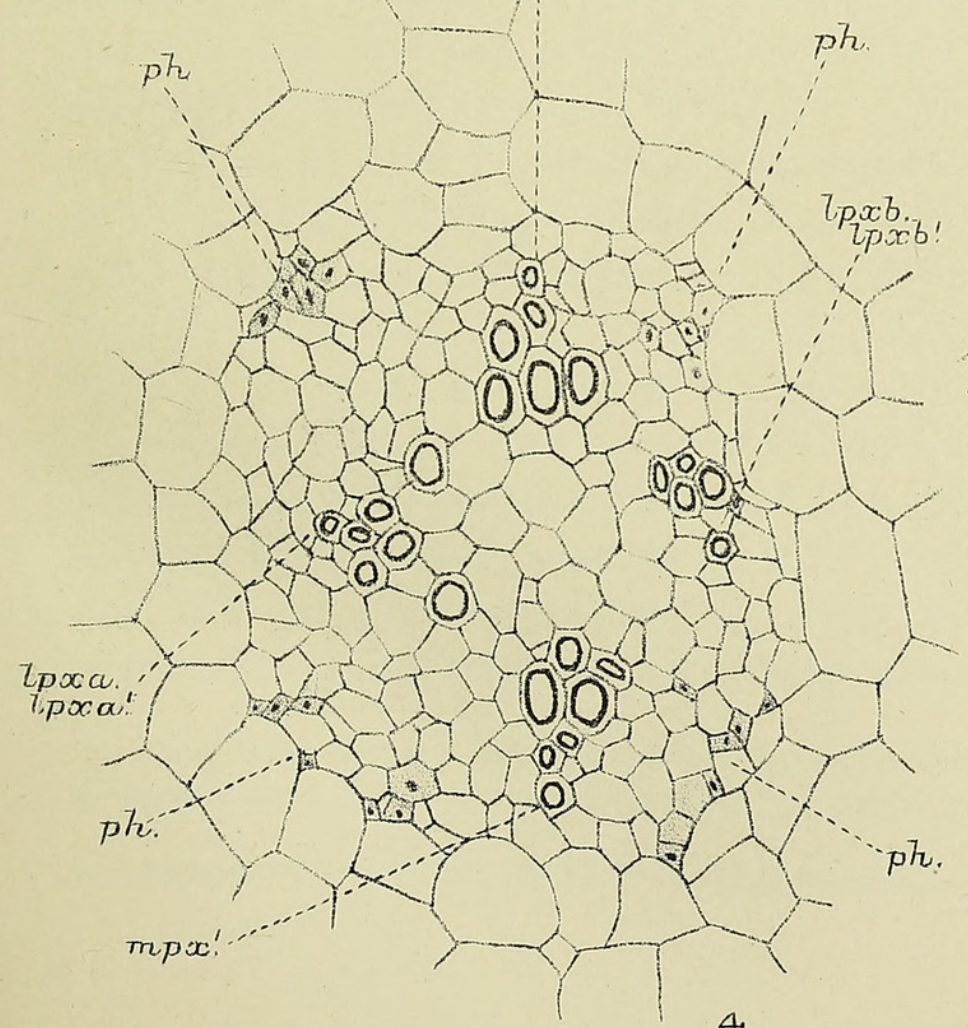

E.Lee, del

4

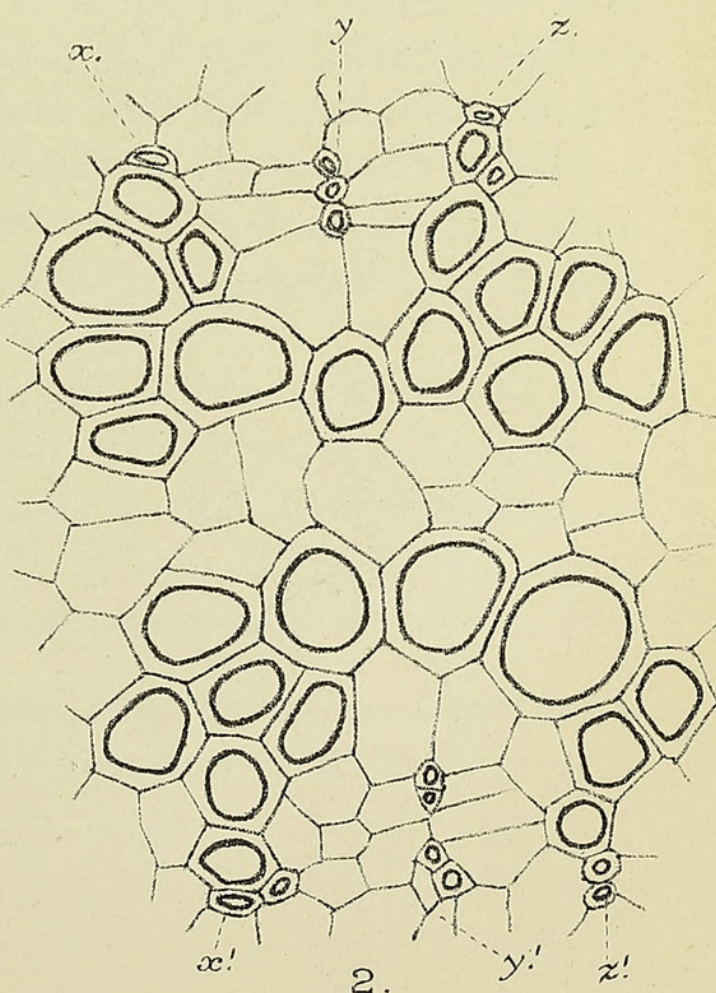

LEE - SEEDLING ANATOMY. 


\section{$2 \mathrm{BHL}$ Biodiversity Heritage Library}

Lee, E. 1912. "Observations on the seedling anatomy of certain Sympetalae. I. Tubiflorae." Annals of botany 26, 727-746.

https://doi.org/10.1093/oxfordjournals.aob.a089412.

View This Item Online: https://www.biodiversitylibrary.org/item/236930

DOI: https://doi.org/10.1093/oxfordjournals.aob.a089412

Permalink: https://www.biodiversitylibrary.org/partpdf/319925

\section{Holding Institution}

Smithsonian Libraries

\section{Sponsored by}

Biodiversity Heritage Library

\section{Copyright \& Reuse}

Copyright Status: Not in copyright. The BHL knows of no copyright restrictions on this item.

This document was created from content at the Biodiversity Heritage Library, the world's largest open access digital library for biodiversity literature and archives. Visit BHL at https://www.biodiversitylibrary.org. 